\title{
Performance Analysis of Photovoltaic Systems and Energy Return on the Environment Economy
}

\section{Murad A. A. Almekhlafi ${ }^{1}$, Fahd N. Al-Wesabi ${ }^{2,3}$, Anwer Mustafa Hilal ${ }^{4}$, Manar Ahmed Hamza ${ }^{4, *}$, Abdelzahir Abdelmaboud ${ }^{5}$ and Mohammed Rizwanullah ${ }^{4}$}

\author{
${ }^{1}$ Department of Electrical Engineering, Communication Engineering, Sana'a University, Yemen \\ ${ }^{2}$ Department of Computer Science, King Khalid University, Muhayel Aseer, Saudi Arabia \\ ${ }^{3}$ Faculty of Computer and IT, Sana'a University, Sana'a, Yemen \\ ${ }^{4}$ Department of Computer and Self Development, Preparatory Year Deanship, Prince Sattam bin Abdulaziz University, AlKharj, \\ Saudi Arabia \\ ${ }^{5}$ Department of Information Systems, King Khalid University, Muhayel Aseer, Saudi Arabia \\ *Corresponding Author: Manar Ahmed Hamza. Email: ma.hamza@psau.edu.sa \\ Received: 29 May 2021; Accepted: 16 July 2021
}

\begin{abstract}
Using fossil fuels and non-renewable forms of energy has many adverse effects on the global ecosystem, and global demand exceeds the limited available resources. Renewable energy is one of the essential elements of social and economic development in any civilized country. This study comprises a feasibility study of the implementation of PV systems in a hybrid diesel network and analyzes the relationship between the effective uses of photovoltaic systems, the return of energy to the environment, and that country's national economy. As a potential solution for the public and private utilities, the sunny web design application was used to calculate of all equipment requirements, presents a cost-effective analysis of electricity saving, and simulate PV/diesel-hybrid systems. Detailed results show that using photovoltaic systems can foster positive developments in several areas (for cost comparisons, effective savings, sensitivity analyses, photovoltaic system costs, photovoltaic system financing, generator operation, and investment costs) for up to 20 years or more and simultaneously reduce $\mathrm{CO}_{2}$ emissions significantly. Therefore, this study conducts an intensive assessment of renewable energy potential for government and private facilities (ministries, universities, hospitals, schools, etc.), which will provide useful insights for renewable energy engineers.
\end{abstract}

Keywords: Hybrid renewable energy; economic dispatch; energy efficiency; photovoltaic performance

\section{Introduction}

Energy is a critical element of social and economic development in any civilized country. Using fossil fuels and non-renewable forms of energy has many adverse effects on the global ecosystem, and global demand exceeds the limited available resources [1-3]. The use of fossil fuels and non-renewable forms

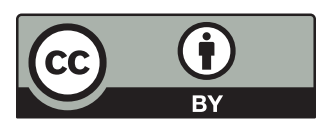

This work is licensed under a Creative Commons Attribution 4.0 International License, which permits unrestricted use, distribution, and reproduction in any medium, provided the original work is properly cited. 
has numerous adverse ecological effects, regionally and globally [4]. Therefore, many countries are following various paths and allocating the necessary sums to develop products and conduct research related to the exploitation of solar energy as one of the essential sources of alternative energy sources to oil and gas [5-8]. The global interest in searching for energy resources to reduce the problems of using fossil fuels has led to the emergence of research in various energy resources, including hybrid systems. These systems operate with full conventional and non-conventional sources [9-14].

We also find that the third world countries [15-19] are facing a bigger problem, which is the general electricity outage due to the political and financial conditions in some countries, which are considered one of the main problems in the country. Because the generation of electricity from the main stations of government and private service facilities (hospitals, ministries, schools, universities, and residential buildings) has stopped, and thus the absence and rise of petroleum products and the absence of the government.

Countries with poor access to electricity and heavy reliance on isolated diesel generation make them a promising candidate for off-grid solar modulation. Thinking about finding solutions to these problems has become an urgent necessity. Renewable energy (solar energy) is the best solution to the reality of those countries and at the same time for many civilized countries.

The research aims to provide a solution to one of the basic problems plaguing the environment. This is done through an analytical study of the use of PV/Diesel Hybrid systems through the application of Sunny Web Design, which is characterized by a variety of analyzes (cost comparisons, effective savings and sensitivity analyzes, costs of PV systems, and systems financing PV and investment costs) for twenty years. This strengthens and clarifies the current and future use of PV/Diesel Hybrid systems in government and private organizations from an economic and financial perspective. The paper also contributes to encouraging governments, the private sector, and engineers to provide and use hybrid systems and renewable energy.

The rest of the article is structured. In Section 2, we explain the current work done so far. The methodology is presented in Section 3. Simulation and discussion are provided in Section 4, and finally, we conclude the article in Section 5.

\section{Related Work}

Various Many studies have been done on this topic; for example [20-22], Kumar et al. [15] presented a case study of a PV/battery/diesel hybrid power system for continuous electricity supply to a school in India. The study used simulation software for improvement, technical and economic analysis, and the effectiveness of reducing carbon dioxide emissions for this hybrid power system compared to a standalone diesel generator system. The simulation result shows that the solar PV diesel system is the most cost-effective and environmentally friendly compared to the diesel/battery generator system, as the system provides a $95 \%$ reduction in carbon dioxide production.

Adesanya et al. [16] presented assessing the economic viability of PV/diesel hybrid systems in Nigerian private sector companies that use levelized cost of energy LCOE in captive power generation, and also analyzed policies that could facilitate investment in solar PV. Forty private companies were surveyed across Nigeria to study the potential fuel savings that a hybrid PV/Diesel system could achieve, and loads of three companies were modeled and simulated among them, which had savings between $€ 0.002$ and $0.009 / \mathrm{kWh}$. Alayan [17] was presented to integrate photovoltaic generators into a system connected to an unreliable diesel network in the Lebanese village of Khiam, in order to reduce the consumption and import of diesel. The study provided a load profile for 120 beds and a pre-design of the PV generator size, storage system capacity, and inverter type/size selection. In addition, simulations and financial analysis were conducted for four different designs starting from the current system (diesel generator DG 
—unreliable network), followed by (PV generator — unreliable network), then (PV—DG), and ending with the complete hybrid system (PV-DG-unreliable network).

The study showed a PV System sharing rate of 53\% and a project life cycle of 25 years. The cost of producing electricity from the hybrid photovoltaic system will be reduced by $53 \%$ of the cost paid to the independent diesel operator, and the system will also provide for a reduction in the production of carbon dioxide by $65 \%$.

\section{Methodology}

Given the issues outlined above, we believe that it is essential to solving these problems, more importantly, hybrid energy shows extraordinary potential for developing and remote countries, many of which need rapid electricity growth, on the one hand, and on the other hand, civilized countries, the economy of states and the environment in general. As is conveyed in this research, a hybrid system consists of PV and diesel was selected to ensure continuous power savings by ensuring that the two power sources operate side by side. This work aims to conduct a feasibility study for the implementation of PV systems in a hybrid diesel network using sunny design software [23]. For the calculation of all equipment needs and to conduct a cost-effective analysis of the electricity-saving project, we mean here from the word project that it can be applied to any Corporation government or private sector, for example. The main general structure of the implementation steps of the research methodology is depicted in Fig. 1.

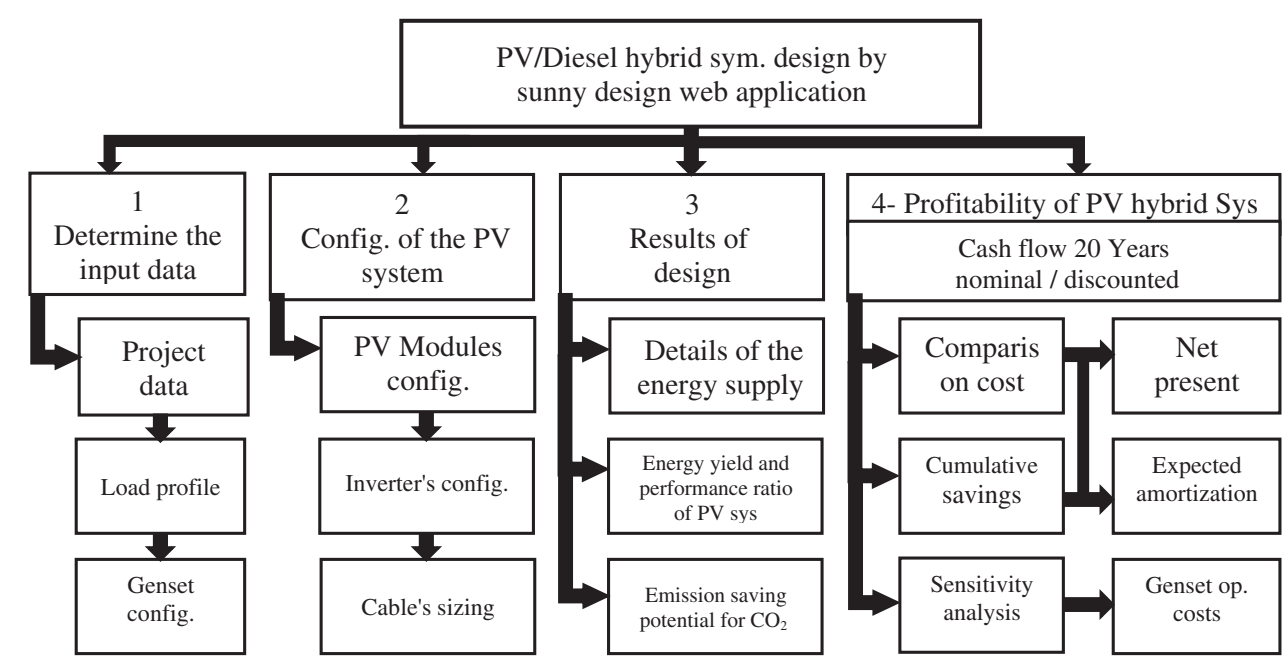

Figure 1: The general structure of the steps of the research methodology utilized in this study

\section{Simulation and Discussion}

In this paper, the proposed hybrid system is simulated and analyzed by the sunny design web software by using four different configurations: A PV project, a PV project with self-consumption, a PV project without grid connection, and PV-hybrid project. The PV-diesel hybrid system was selected in this study.

\subsection{Determining the Input Data of the System}

The input data that to needed in system design consist of several types as position coordinates of case study, load profile, and gensets configuration.

\subsubsection{Project Data}

Project data contains the project name, customer, and location of the building. 


\subsubsection{Load Profile}

It is essential to create a power load profile which is the total power required from a power system or subsystem over a specified period (hours, days, etc.). What is the best way to download such a system for time changes? The data of the load profile depends on the main daytime loads of the service facilities in the ministry, which are detailed in Tab. 1. Note that the Project works during the day only [24].

Table 1: Load list of the project

\begin{tabular}{lllll}
\hline Name & Qty & $\begin{array}{l}\text { Cap. } \\
\text { W }\end{array}$ & $\begin{array}{l}\text { Rated power } \\
\text { KW }\end{array}$ & $\begin{array}{l}\text { Daily energy } \\
\text { cons. KWh/day }\end{array}$ \\
\hline Server & 2 & 1500 & 3 & 24 \\
Computers & 74 & 190 & 14.06 & 98.42 \\
Printers & 32 & 510 & 16.32 & 97.92 \\
Copy machines & 13 & 1100 & 14.3 & 71.5 \\
Lamps & 30 & 40 & 1.2 & 9.6 \\
Vacuum cleaner & 3 & 2000 & 6 & 18 \\
Left & 2 & 6250 & 12.5 & 35 \\
Air conditioner & 2 & 2000 & 4 & 28 \\
Water heater & 2 & 2000 & 4 & 16 \\
Water fountain & 5 & 500 & 2.5 & 20 \\
Cafeteria & 1 & 2000 & 2 & 14 \\
Total & & & $79.88 \mathrm{KW}$ & $432.44 \mathrm{KWh}$ \\
\hline
\end{tabular}

To defining the load profile using the sunny web design application, the selecting of the breakdown of the seasons was accrued as shown in Fig. 2, and the daily consumption at all seasons was entered according to the list in Tab. 1 above and can be shown in Figs. 3 and 4 below. The sunny design web software was calculated the load profile as $62425 \mathrm{~W}$.

Breakdown of seasons into months

Summer

$\square$ 05-06 to $08-05$
Spring/fall
$\square$ 02-06 to 05-05 and 08-06 to 11-05
Winter
$\square$ t1-06 $02-05$

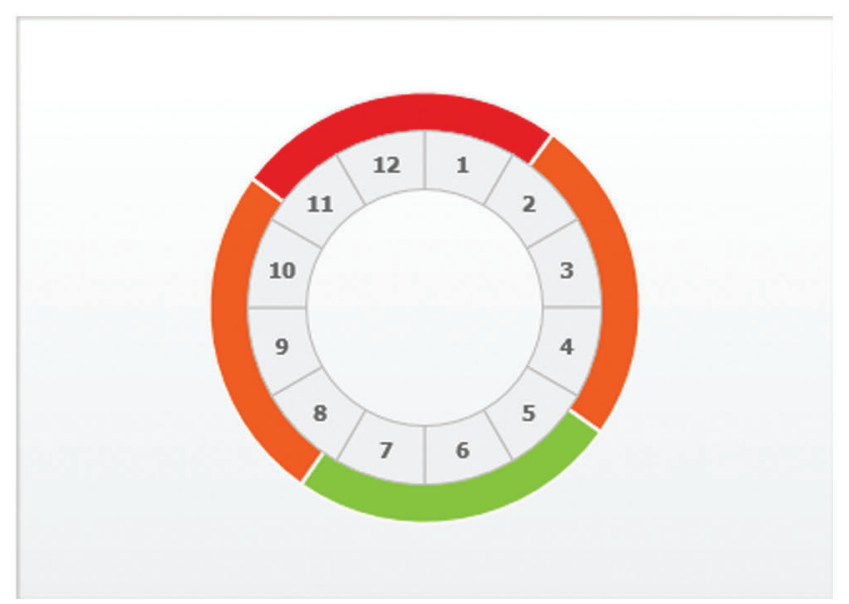

Figure 2: Determining the date of the season in the sunny design web app 


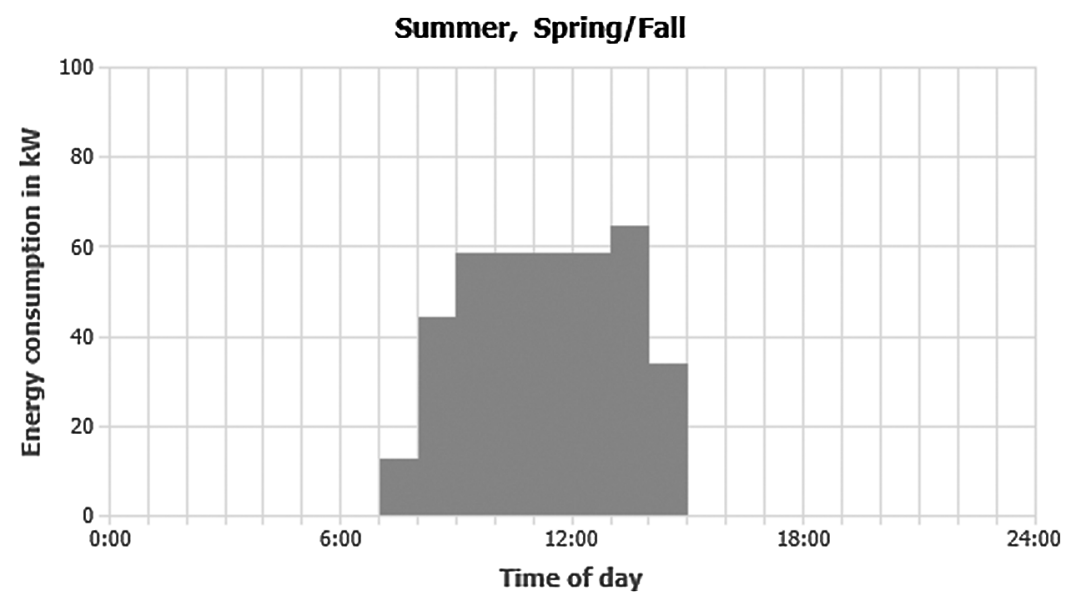

Figure 3: The daily load profile in summer/spring/fall

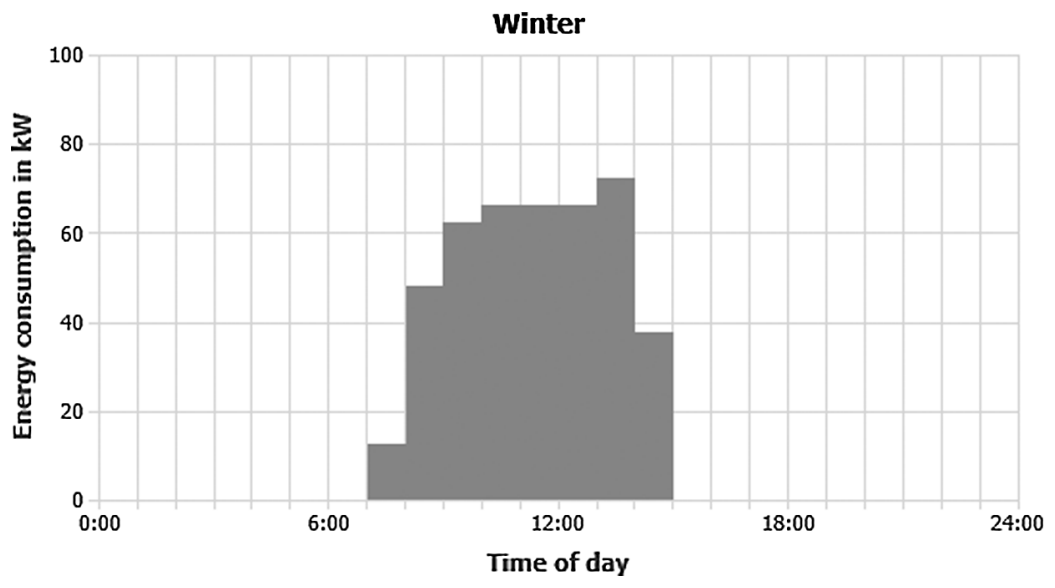

Figure 4: The daily load profile in winter

Then the average weekly profile by seasons was entered as can be seen in Fig. 5 below. The average seasonal profiles are shown in Tab. 2.

\subsubsection{Genset Configuration}

The generator was diesel-powered, and its active power must be greater from load profile $62425 \mathrm{~W}$, as $64 \mathrm{~kW}$. The common power factor was 0.8 was chosen, and the capacity become approximately $80 \mathrm{kVA}$. The minimum load was chosen $20 \%$. Tab. 3 shows the design conditions of genset.

\subsection{Configuration of the PV System for Hybrid Renewable Energy}

The next step in software is the configuration of the PV system, the PV system configuration contains PV modules, inverters, and cables.

\subsubsection{PV Modules Configuration}

When starting that, the software introduces a suggestion to select the optimum PV power (44 kVA) needed to share with genset. To guarantee a smooth operation with the gensets, the share of the PV power in the PV hybrid system must not, however, exceed the technical maximum. The technical max is $60 \%$ of the apparent power of the gensets (48 kVA) operated at the same time during the day as illustrated in Fig. 6. 


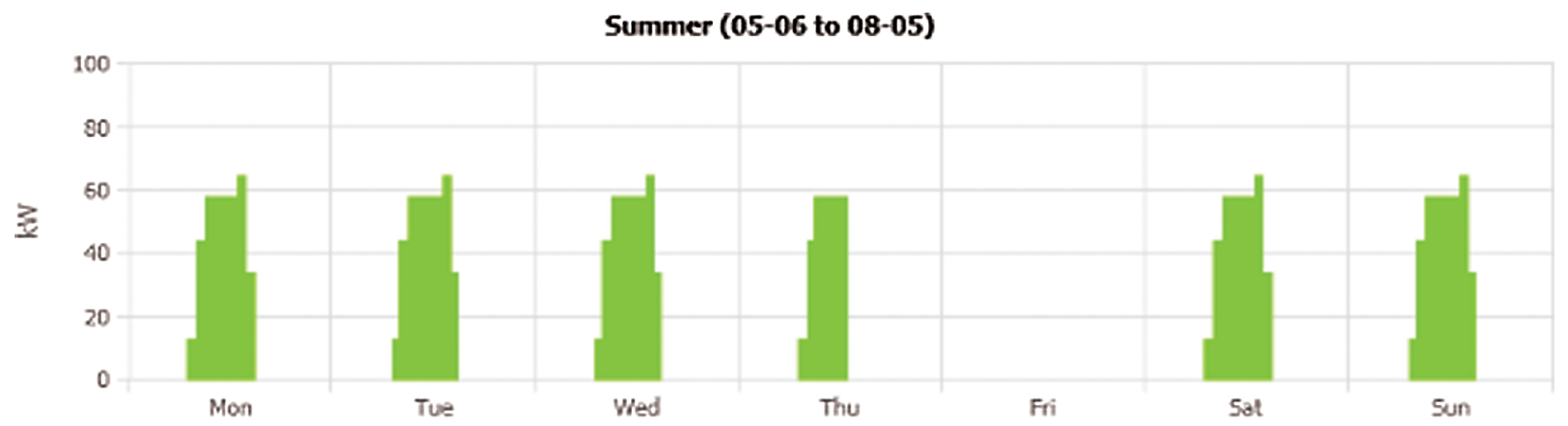

Spring/fall (02-06 to 05-05 and 08-06 to 11-05)

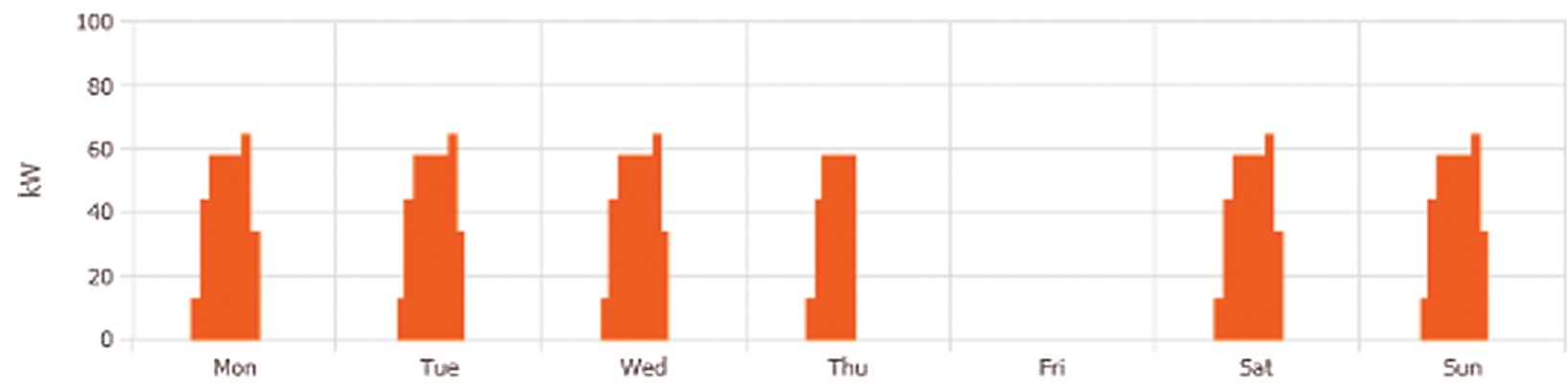

Winter (11-06 to 02-05)

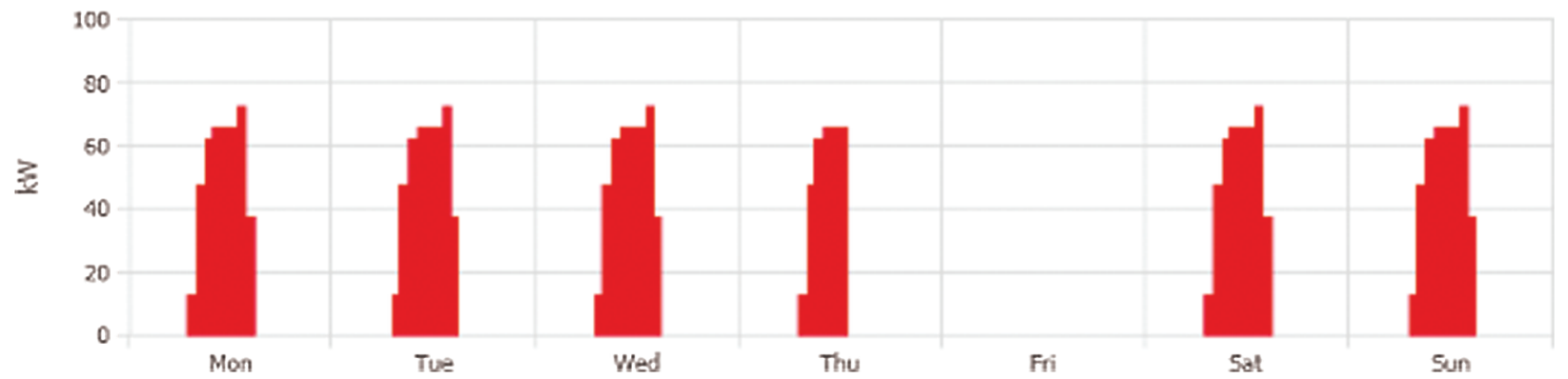

Figure 5: Average weekly profile of the seasons

Table 2: Average seasonal profiles

\begin{tabular}{lllll}
\hline & Year & Summer & Spring/Fall & Winter \\
\hline Min. power requirement & $1,4000 \mathrm{~W}$ & $1,4000 \mathrm{~W}$ & $2,800 \mathrm{~W}$ & $2,400 \mathrm{~W}$ \\
Max. power requirement & $72,380 \mathrm{~W}$ & $64,380 \mathrm{~W}$ & $64,380 \mathrm{~W}$ & $72,380 \mathrm{~W}$ \\
Av. daily requirement & $328 \mathrm{kWh}$ & $320 \mathrm{kWh}$ & $319 \mathrm{kWh}$ & $356 \mathrm{kWh}$ \\
Energy requirement & $120 \mathrm{MWh}$ & $29,411 \mathrm{kWh}$ & $57,657 \mathrm{kWh}$ & $32,731 \mathrm{kWh}$ \\
\hline
\end{tabular}

In this design, the 300-watt PV module was chosen, and a total number of PV modules was 144, which has been divided into three arrays, each containing 48 modules with a capacity of $43.2 \mathrm{~kW}$. 
Table 3: Design conditions of genset

\begin{tabular}{|c|c|c|c|}
\hline \multicolumn{4}{|l|}{ Overall view } \\
\hline & Gensets & \multicolumn{2}{|l|}{ Load profile } \\
\hline Max apparent power & $100 \mathrm{kVA}$ & \multicolumn{2}{|l|}{$79618 \mathrm{VA}$} \\
\hline Max. active power & $80 \mathrm{~kW}$ & \multicolumn{2}{|l|}{$79618 \mathrm{~W}$} \\
\hline Quantity of the gensets & \multicolumn{3}{|l|}{1} \\
\hline Average genset efficiency & \multicolumn{3}{|l|}{$2.32 \mathrm{kWh} / 1$} \\
\hline \multicolumn{4}{|l|}{ Design conditions } \\
\hline \multicolumn{4}{|c|}{$\begin{array}{l}\text { The minimum power of the gensets, adjusted for the load, takes into account an additional power reserve } \\
\text { that can be provided by the gensets. A load-related minimum power of } 110 \% \text { means a power reserve of } \\
10 \% \text {. The minimum PV power to be expected shows what portion of the original PV power can be expected } \\
\text { if clouds suddenly appear. }\end{array}$} \\
\hline \multicolumn{2}{|l|}{ Minimum genset load } & \multicolumn{2}{|l|}{$20 \%$} \\
\hline \multicolumn{2}{|c|}{ Load-related minimum power } & \multicolumn{2}{|c|}{$110 \%$ (of the maximum power requirement) } \\
\hline \multicolumn{2}{|c|}{ Minimum PV power to be expected } & \multicolumn{2}{|c|}{$20 \%$ (of the possible PV power with no clouds) } \\
\hline \multicolumn{4}{|c|}{ Maximum permissible PV inverter power } \\
\hline \multicolumn{4}{|c|}{$\begin{array}{l}\text { The genset reference power takes into consideration the design conditions and the gensets that are necessary } \\
\text { at the same time during the day. The resulting maximum PV inverter power is } 60 \% \text { of the genset reference } \\
\text { power. }\end{array}$} \\
\hline \multirow{2}{*}{\multicolumn{2}{|c|}{$\begin{array}{l}\text { Genset reference power for PV dimensionir } \\
\text { Resulting max. PV inverter power }\end{array}$}} & \multicolumn{2}{|c|}{$100.00 \mathrm{kVA}$} \\
\hline & & 60.0 & VA \\
\hline \multicolumn{4}{|l|}{ A detailed list of the gensets } \\
\hline Apparent power & Active power & $\begin{array}{l}\text { Fuel consumption at } \\
\text { nominal power }\end{array}$ & Genset efficiency at nominal power \\
\hline Genset $1100 \mathrm{kVA}$ & $80 \mathrm{~kW}$ & $22.9 \mathrm{l} / \mathrm{h}$ & $3.50 \mathrm{kWh} / 1$ \\
\hline
\end{tabular}

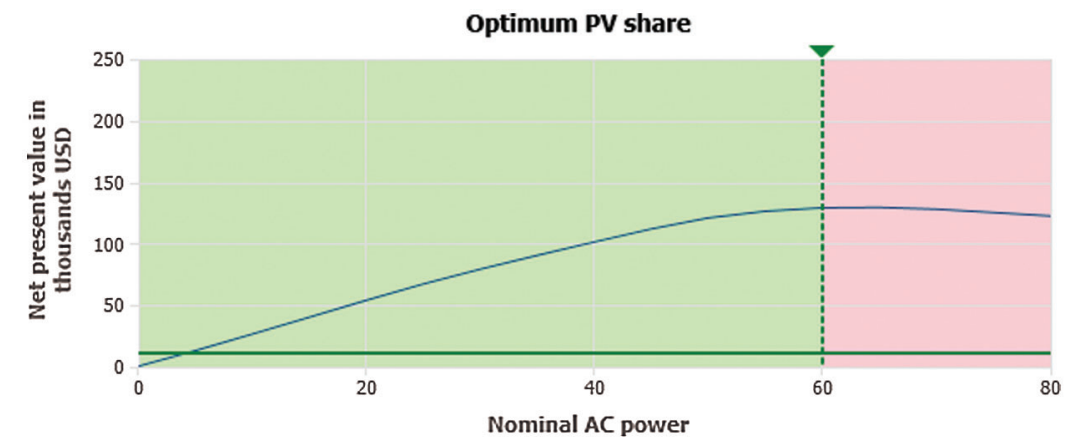

Figure 6: Suggestion to select the optimum PV power needed to share with genset

\subsubsection{Inverters Configuration}

In order to achieve great compatibility between the inverters and the PV arrays, 3 inverters with a capacity of $15 \mathrm{~kW}$ were selected (inverters for each array). The PV modules and inverters designed data is revealed in Tab. 4. 
Table 4: PV modules and inverters designed data

\begin{tabular}{ll}
\hline Name & Value \\
\hline Arinna AG peak power 60-230 & \\
Power of PV module & $230 \mathrm{~W}$ \\
No. cells & 60 \\
Total number of PV modules & 264 \\
Peak power & $60.72 \mathrm{kWp}$ \\
Number of PV inverters & 3 \\
Nominal AC power of PV inverters & $60.00 \mathrm{~kW}$ \\
AC active power & $60.00 \mathrm{~kW}$ \\
Active power ratio & $98.8 \%$ \\
Max. available PV energy & $120.42 \mathrm{MWh}$ \\
Energy usability factor & $99.7 \%$ \\
Spec. energy yield & $1983 \mathrm{kWh} / \mathrm{kWp}$ \\
Used PV energy & $69,956.01 \mathrm{kWh}$ \\
Used PV share & $58.1 \%$ \\
PV share of energy supply (total) & $58.4 \%$ \\
PV share of the energy supply (during the day) & $58.4 \%$ \\
\hline
\end{tabular}

\subsubsection{Cables Sizing}

The power loss of the selected cable sizing can be calculated here. The recommends a relative power loss with the rated operation of less than $1 \%$ on the AC side or the DC side. Tab. 5 shows the cables sizing and power loss of the system design [25].

Table 5: Cable's sizing and power loss

\begin{tabular}{llll}
\hline Item & DC side & AC side & Total \\
\hline Power loss at nominal operation & $186.45 \mathrm{~W}$ & $121.93 \mathrm{~W}$ & $308.38 \mathrm{~W}$ \\
Rel. power loss at rated nominal operation & $0.35 \%$ & $0.27 \%$ & $0.62 \%$ \\
Total cable length & $240.00 \mathrm{~m}$ & $30.00 \mathrm{~m}$ & $270.00 \mathrm{~m}$ \\
Cable cross-sections & $2,5 \mathrm{~mm}^{2}$ & $6 \mathrm{~mm}^{2}$ & $2,5 \mathrm{~mm}^{2}$ \\
& & & $6 \mathrm{~mm}^{2}$ \\
\hline
\end{tabular}

After defining the load, the PV and generator were configured. The hybrid system configuration is shown in Fig. 7.

\subsection{Discussion}

This subsection presents a discussion in detail of the proposed hybrid system in the following subsections. 


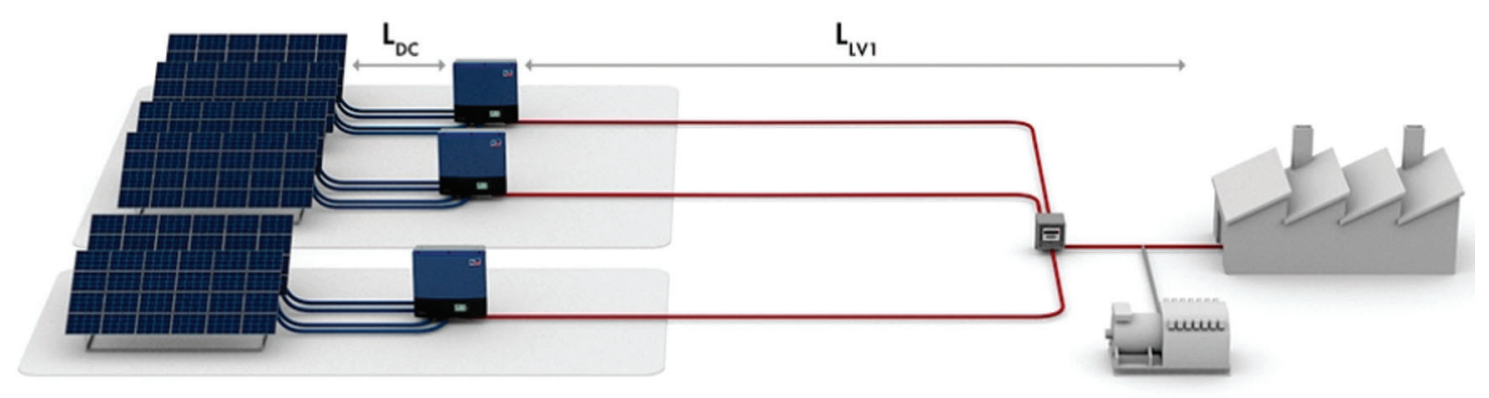

Figure 7: Hybrid power system structure

\subsubsection{Details of the Energy Supply}

The annual energy consumption in this hybrid system reached $444 \mathrm{~kW}$, which resulted from the annual generation of the generator of $41,412.68 \mathrm{kWh}$, consuming 17,823 liters of diesel annually, plus the annual use of PV system of 48,361.07 kWh, saving 11,177 liters of diesel annually as illustrated in Fig. 8 and Tab. 6. We note that the PV share of the energy supply reached $53.9 \%$, which is a large value close to the maximum value of $60 \%$.

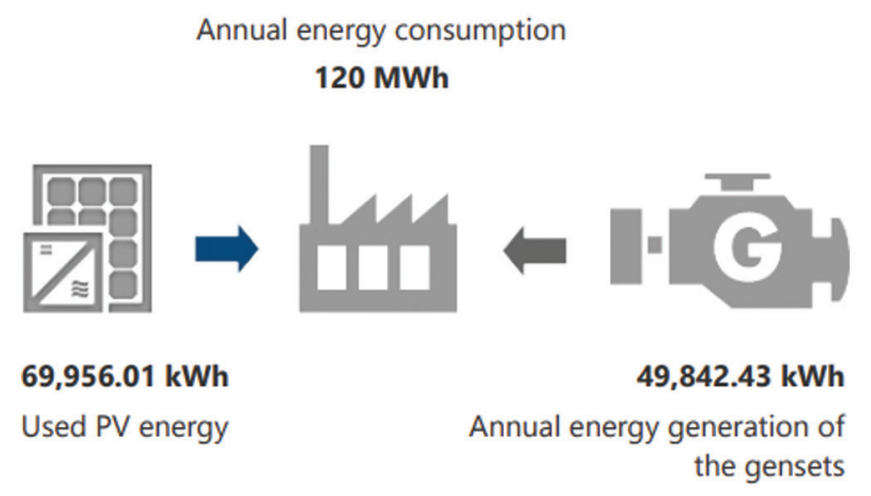

Figure 8: The annual energy consumption in this hybrid system

Table 6: Annual energy and fuel consumption

\begin{tabular}{lllllll}
\hline $\begin{array}{l}\text { Annual } \\
\text { energy } \\
\text { consumption }\end{array}$ & $\begin{array}{l}\text { Annual energy } \\
\text { generation of } \\
\text { the gensets }\end{array}$ & $\begin{array}{l}\text { Fuel } \\
\text { consumption } \\
\text { per year } \\
\text { (approx.) }\end{array}$ & $\begin{array}{l}\text { Used PV } \\
\text { energy }\end{array}$ & $\begin{array}{l}\text { Annual } \\
\text { fuel } \\
\text { savings } \\
\text { potential } \\
\text { (approx.) }\end{array}$ & $\begin{array}{l}\text { PV share } \\
\text { of the } \\
\text { energy } \\
\text { supply } \\
\text { (total) }\end{array}$ & $\begin{array}{l}\text { PV share of } \\
\text { the energy } \\
\text { supply } \\
\text { (during the } \\
\text { day) }\end{array}$ \\
\hline $120 \mathrm{MWh}$ & $49,842.43 \mathrm{kWh}$ & $21,441 \mathrm{~L}$ & $69,956.01 \mathrm{kWh}$ & $16,452 \mathrm{~L}$ & $58.4 \%$ & $58.4 \%$ \\
\hline
\end{tabular}

\subsubsection{Energy Yield and Performance Ratio of PV Systems}

The maximum available PV energy annual is $85,492.58 \mathrm{kWh}$, but the use of PV energy is $48,361.07 \mathrm{kWh}$, where the used PV share ratio is $56.6 \%$. Fig. 9 shows the daily energy consumption, the daily maximum available PV energy, and daily used PV energy in the lowest and highest yield. 


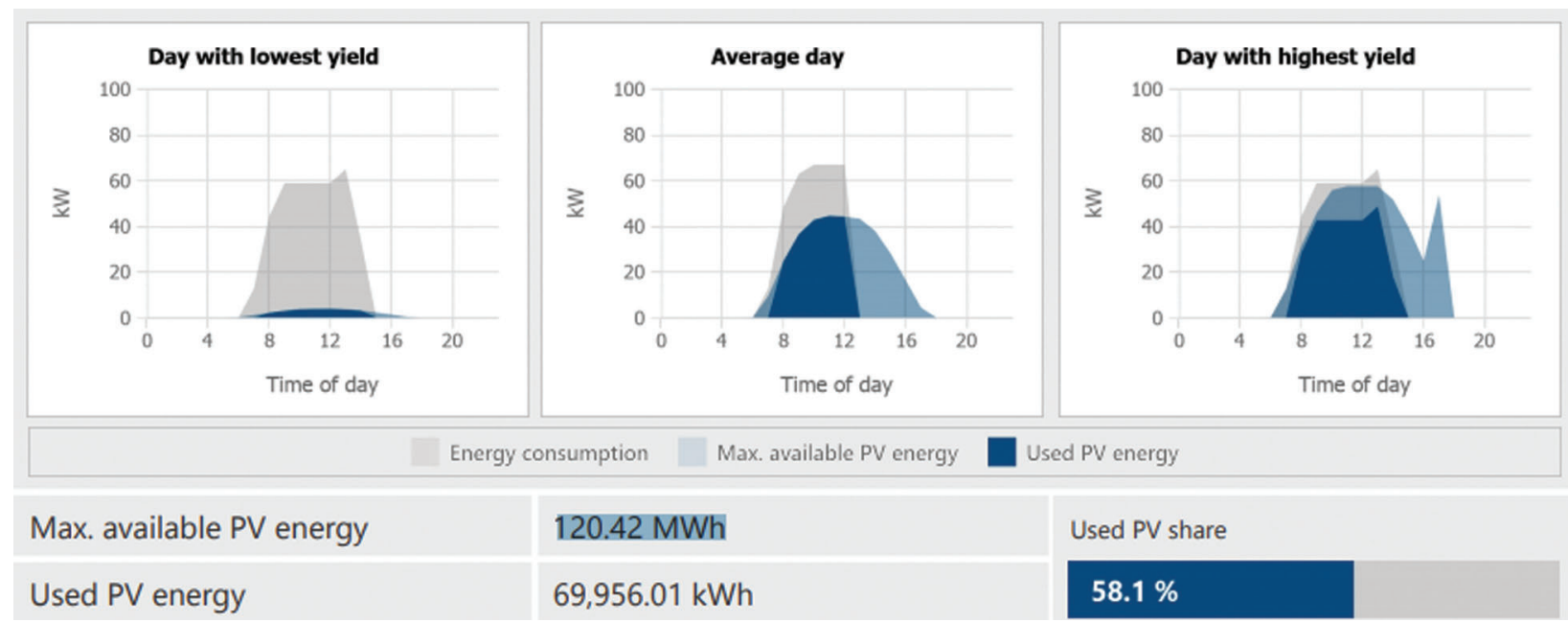

Figure 9: The annual daily energy consumption and available PV energy

\subsubsection{Emission Saving Potential for $\mathrm{CO}_{2}$}

It is known that burning fossil fuels to produce power produces carbon dioxide gases that are harmful to both the environment and humans alike. Because carbon dioxide gas is toxic and affects human health, constant exposure leads to adverse effects. When it accumulates in the atmosphere, it fosters global warming. Therefore, it is necessary to reduce $\mathrm{CO}_{2}$ emissions by using renewable energy and the aim of this study is to reduce the emissions of this toxic gas [26]. The fuel and $\mathrm{CO}_{2}$ savings potential per year is 30 tons and the relative fuel/ $\mathrm{CO}_{2}$ emission savings potential per year is $38.5 \%$, and shown in Tab. 7 , below.

Table 7: Details of the energy supply

\begin{tabular}{lll}
\hline $\begin{array}{l}\text { Fuel savings potential } \\
\text { per year }\end{array}$ & $\begin{array}{l}\mathrm{CO}_{2} \text { emission savings potential } \\
\text { per year }\end{array}$ & $\begin{array}{l}\text { Relative fuel } / \mathrm{CO}_{2} \text { emission savings } \\
\text { potential per year }\end{array}$ \\
\hline $16,452 \mathrm{~L}$ & 44 ton & $43.4 \%$ \\
\hline
\end{tabular}

\subsection{Profitability of the PV Hybrid System}

In Tab. 8, note the profitability of the hybrid photovoltaic system, where the investment costs of the ready-made photovoltaic system (CapEx) are $\$ 43,200$, and the annual fuel savings potential is about 11,177 liters annually, providing a cash value of $\$ 8,940$ per year, making the expected amortization period less than 5 years.

Table 8: Profitability of the PV hybrid system

\begin{tabular}{|c|c|c|c|c|c|}
\hline $\begin{array}{l}\text { Investment } \\
\text { costs of the } \\
\text { PV system } \\
\text { (CapEx) }\end{array}$ & $\begin{array}{l}\text { Annual fuel } \\
\text { savings } \\
\text { potential } \\
\text { (approx.) }\end{array}$ & $\begin{array}{l}\text { Annual cash } \\
\text { value savings } \\
\text { potential } \\
\text { (approx.) }\end{array}$ & $\begin{array}{l}\text { Expected } \\
\text { amortization } \\
\text { period in years } \\
\text { (approx.) }\end{array}$ & $\begin{array}{l}\text { Net present value } \\
\text { using discounted } \\
\text { cash flow }(8.0 \% \text { p.a. } \\
\text { discount })\end{array}$ & $\begin{array}{l}\text { Net present } \\
\text { value using } \\
\text { nominal cash } \\
\text { flow (approx.) }\end{array}$ \\
\hline 60,720 USD & $16,452 \mathrm{~L}$ & 13,162 USD & 5 Years & 119,821 USD & 359,816 USD \\
\hline
\end{tabular}




\subsubsection{Cash Flow}

For analysis of the cash flow, you can choose between nominal and discounted cash flow. In the cost comparison, the investment and maintenance costs of the gensets are not considered since they are almost identical for a PV hybrid system and a conventional genset system. The net present value using nominal and discounted cash flow also was shown in Tab. 8 [27], and the Figs. 10 and 12 show the cost comparison, cumulative savings, and sensitivity analysis for discounted cash flow ( $8.0 \%$ p.a. discount), whilst the Figs. 11 and 13 show the cost comparison, cumulative savings, and sensitivity analysis for nominal cash flow. It is apparent that the value of the generator in the first years is less and increases from the fourth year.

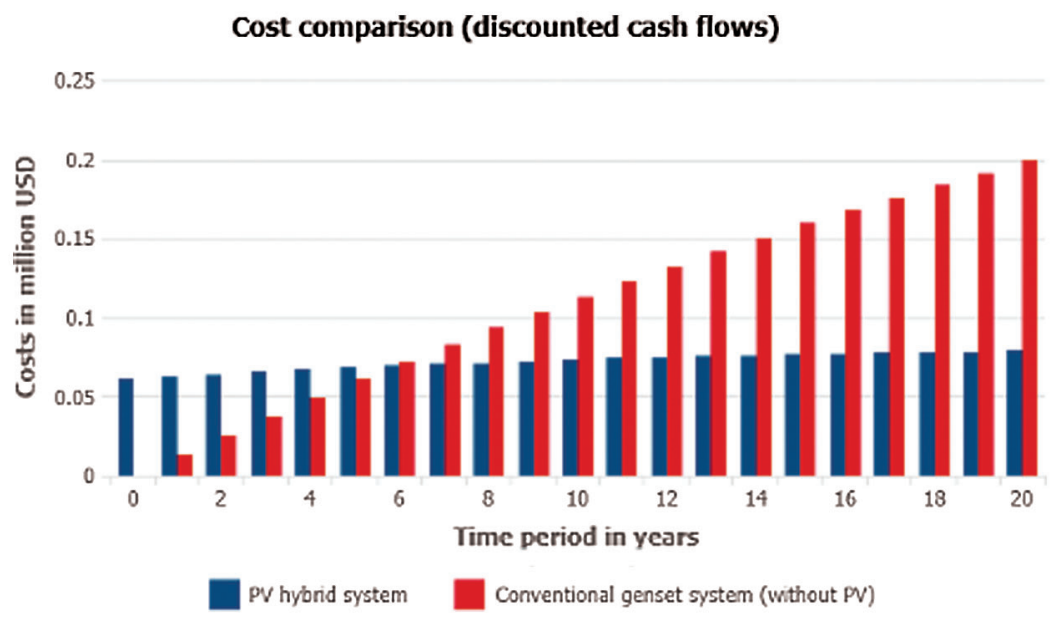

Figure 10: The cost comparison (discounted cash flow)

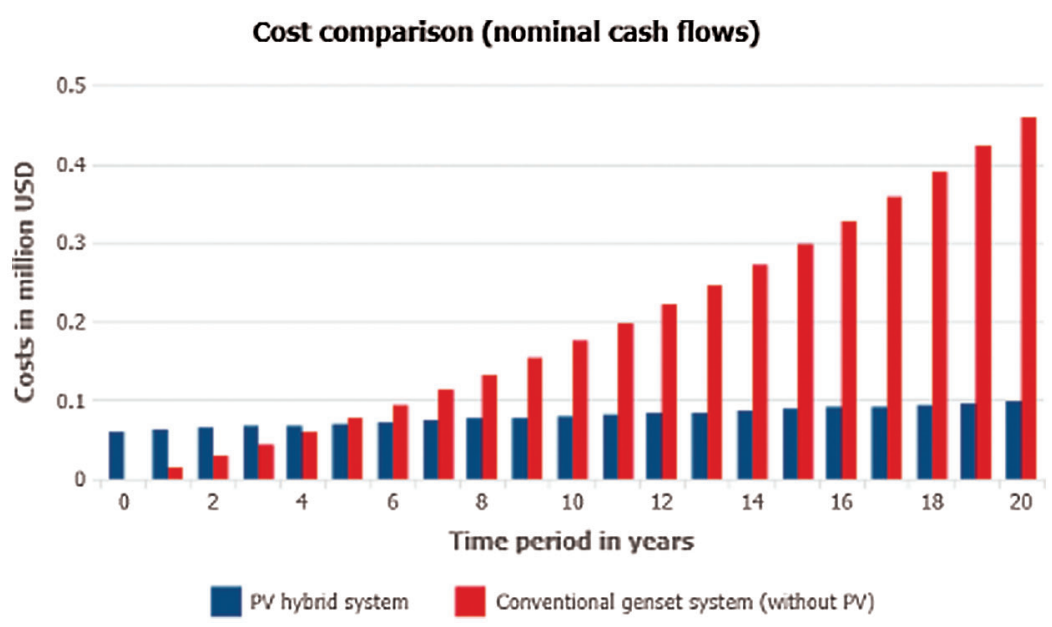

Figure 11: The cost comparison (nominal cash flow)

Figs. 12 and 13 show that the cumulative savings of cost at 20 years, that reach 78,882 USD in the discounted cash flow and 241,335 USD in the nominal cash flow. 


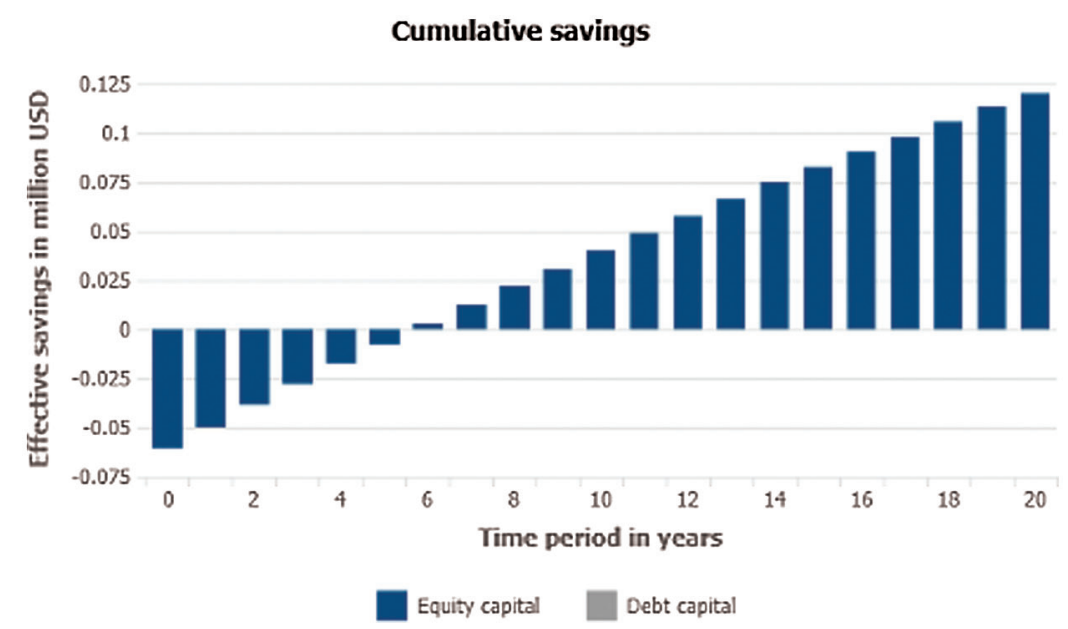

Figure 12: The cumulative savings (discounted cash flow)

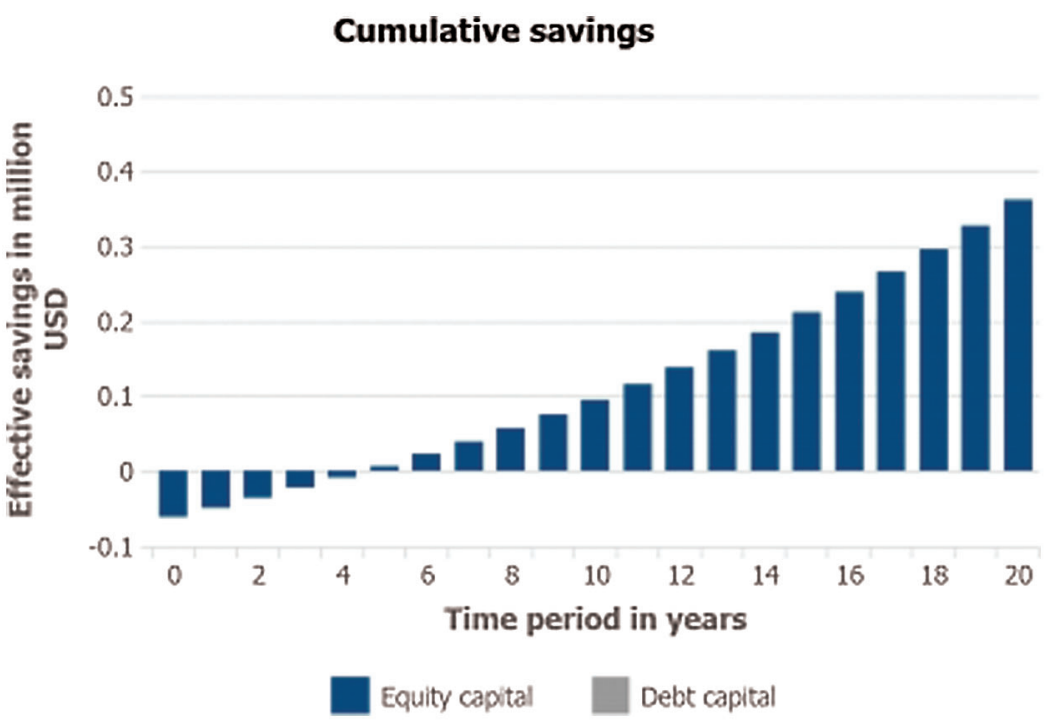

Figure 13: The cumulative savings (nominal cash flow)

\subsubsection{Gensets Operating Costs}

Figs. 14 and 15 shows that the effective fuel cost of the generator decreased from a value of $0.8 \mathrm{USD} / \mathrm{L}$ to a value of $0.34 \mathrm{USD} / \mathrm{L}$ in the discounted cash flow and a value of $0.2 \mathrm{USD} / \mathrm{L}$ in the nominal cash flow. Tab. 9 shows that the average energy efficiency for genset is $2.32 \mathrm{kWh} / 1$, while Energy generation costs (pure fuel costs) are $0.34 \mathrm{USD} / \mathrm{kWh}$ (given that the Effective fuel costs are $0.80 \mathrm{USD} / \mathrm{l}$ ). But this value will decrease over time and after 20 years will become $0.146 \mathrm{USD} / \mathrm{kWh}$. Annual increase in fuel costs has been considered to be $5 \%[28,29]$. 


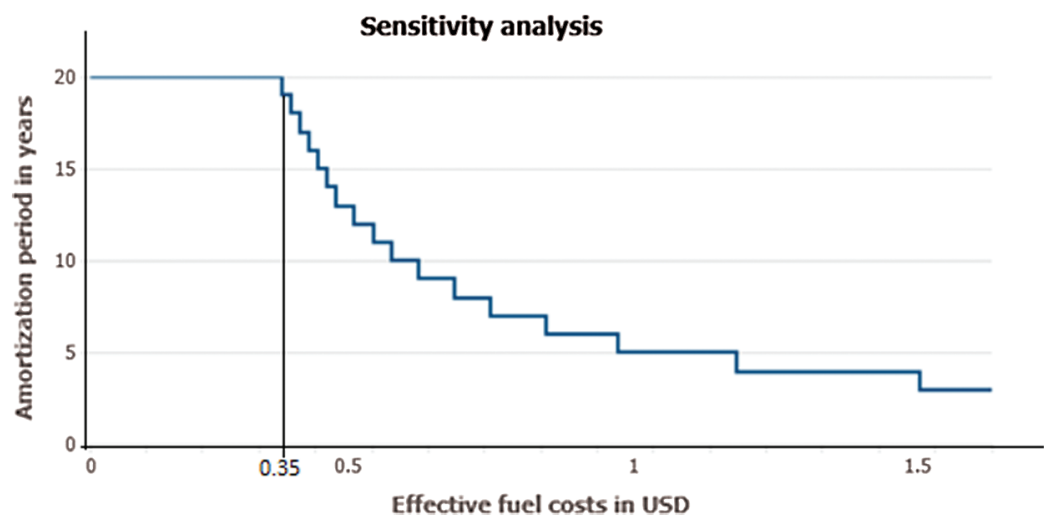

Figure 14: The analysis of fuel costs (discounted cash flow)

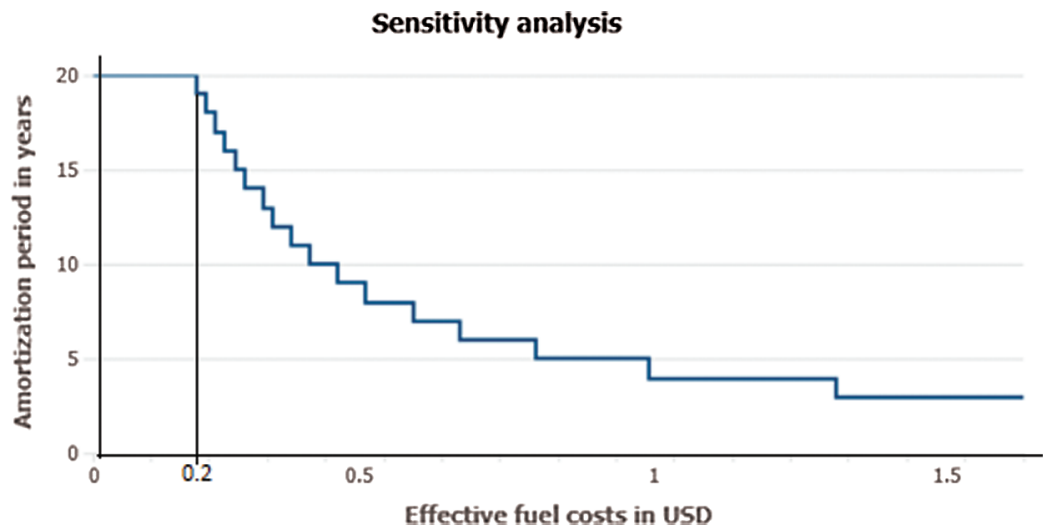

Figure 15: The analysis of fuel costs (nominal cash flow)

Table 9: Gensets operating costs

\begin{tabular}{lllll}
\hline $\begin{array}{l}\text { Effective } \\
\text { fuel costs }\end{array}$ & $\begin{array}{l}\text { Average energy } \\
\text { efficiency }\end{array}$ & $\begin{array}{l}\text { Energy generation costs } \\
\text { (pure fuel costs) }\end{array}$ & $\begin{array}{l}\text { Energy generation costs } \\
\text { (after 20 years) }\end{array}$ & $\begin{array}{l}\text { The annual increase } \\
\text { in fuel costs }\end{array}$ \\
\hline $0.80 \mathrm{USD} / 1$ & $2.32 \mathrm{kWh} / 1$ & $0.34 \mathrm{USD} / \mathrm{kWh}$ & $0.2 \mathrm{USD} / \mathrm{kWh}$ & $5 \%$ \\
\hline
\end{tabular}

\section{Conclusion}

This study comprises a feasibility study of the implementation of PV systems in a hybrid diesel network. Sunny design web software have been used for the calculation of all equipment requirements, and also presents a cost-effective analysis of electricity savings from the proposed project watch that can be applied to any Corporation government or private sector, for example. The most important outcomes of the study can be summarized as follows:

- The total number of PV modules is 264 ( $230 \mathrm{~W}$ per module) and the peak power calculated by these is 60.72 KWp, with three inverters. The CapEx costs of the PV system is 60,720 USD.

- The annual energy consumption is $120 \mathrm{MWh}$, where the annual energy generation of the gensets is $49842 \mathrm{kWh}$ with a ratio $46.1 \%$, whilst the Used PV energy $69,956 \mathrm{kWh}$ with a ratio $58.4 \%$, and the expected amortization period in 5 years. 
- The PV share of the energy supply (during the day) is $58.4 \%$, and this ratio is very good and close to the upper limit $60 \%$.

- The fuel consumption per year of the gensets was decreased from 37,893 to 21,441 Liter of diesel with a ratio $56.57 \%$, where the annual fuel savings potential by PV system is 16,452 Liter with ratio $43.43 \%$.

- The average genset efficiency is $2.32 \mathrm{kWh} / \mathrm{L}$ that equals $0.67 \%$ from the genset efficiency at nominal power $(3.5 \mathrm{kWh} / \mathrm{L})$.

- The net present value using discounted cash flow is $119,821 \mathrm{USD}$, and the net present value using nominal cash flow is 359,816 USD.

- The relative fuel $/ \mathrm{CO}_{2}$ emission savings potential per year is $43.4 \%$.

Funding Statement: The authors extend their appreciation to the Deanship of Scientific Research at King Khalid University for funding this work under Grant Number (RGP. 2/209/42) received by Fahd N. AlWesabi, www.kku.edu.sa.

Conflicts of Interest: The authors declare that they have no conflicts of interest to report regarding the present study.

\section{References}

[1] S. Hashemi, S. Ramakrishna and A. Aberle, "Recent progress in flexible-wearable solar cells for self-powered electronic devices," Energy \& Environmental Science, vol. 13, no. 3, pp. 685-743, 2020.

[2] J. Chen, D. Jia, E. Johansson, A. Hagfeldt and X. Zhang, "Emerging perovskite quantum dot solar cells: Feasible approaches to boost performance," Energy \& Environmental Science, vol. 14, no. 1, pp. 224-261, 2020.

[3] H. Baig, H. Kanda, A. Asiri, M. Nazeeruddin and T. Mallicka, "Correction: Increasing efficiency of perovskite solar cells using low concentrating photovoltaic systems," Sustainable Energy Fuels, vol. 4, no. 8, pp. 43014302, 2020.

[4] P. Huang, Y. Sun, M. Lovati and X. Zhang, "Solar photovoltaic power sharing based design optimization of distributed energy storage systems for performance improvements," Energy, vol. 222, pp. 119931, 2021.

[5] R. Coridan, A. Nielander, S. Francis, M. McDowell, V. Dix et al., "Methods for comparing the performance of energy-conversion systems for use in solar fuels and solar electricity generation," Energy \& Environmental Science, vol. 8, no. 10, pp. 2886-2901, 2015.

[6] I. Laghari, M. Samykano, A. Pandey, K. Kadirgamac and V. Tyagi, "Advancements in PV-thermal systems with and without phase change materials as a sustainable energy solution: Energy, exergy and exergoeconomic (3E) analytic approach," Sustainable Energy Fuels, vol. 4, no. 10, pp. 4956-4987, 2020.

[7] K. Al-Khori, Y. Bicer and M. Koç, "Comparative techno-economic assessment of integrated PV-SOFC and PVBattery hybrid system for natural gas processing plants," Energy, vol. 222, pp. 119923, 2021.

[8] C. Cui and Y. Li, "High-performance conjugated polymer donor materials for polymer solar cells with narrowbandgap nonfullerene acceptors," Energy \& Environmental Science, vol. 12, no. 11, pp. 3225-3246, 2019.

[9] W. Zhang and L. Lu, "Energy performance and heat transfer characteristics of photovoltaic double skin facades (PV-DSFs): A review," Sustainable Energy Fuels, vol. 1, no. 7, pp. 1502-1515, 2017.

[10] J. Cao and F. Yan, "Recent progress in tin-based perovskite solar cells," Energy \& Environmental Science, vol. 14, no. 3, pp. 1286-1325, 2021.

[11] P. Nayak, G. Garcia, A. Kahn, J. Bisquert and D. Cahen, "Photovoltaic efficiency limits and material disorder," Energy \& Environmental Science, vol. 5, no. 3, pp. 6022-6039, 2012.

[12] H. Ziar, P. Manganiello, O. Isabella and M. Zeman, "Photovoltatronics: Intelligent PV-based devices for energy and information applications," Energy \& Environmental Science, vol. 14, no. 1, pp. 106-126, 2020.

[13] C. Balaceanu and G. Iordache, "Assessment of the air pollution at the industrial stations in metropolitan area of Bucharest," Scientific and Technical Journal, vol. 3, pp. 8-15, 2018. 
[14] T. Salameh, C. Ghenai, A. Merabet and M. Alkasrawi, "Techno-economical optimization of an integrated standalone hybrid solar PV tracking and diesel generator power system in Khorfakkan, United Arab Emirates," Energy, vol. 190, pp. 116475, 2019.

[15] M. A. A. Almekhlafi, "Justification of the advisability of using solar energy for the example of the Yemen republic," Scientific and Technical Journal, vol. 4, pp. 41-50, 2018.

[16] Renewables Interactive Map-Country Profile: Yemen, 2015. [Online]. Available: https:/ourworldindata.org/ energy/country/yemen.

[17] International Energy Agency, Statistics on the Web, 2015. [Online]. Available: https://www.irena.org/statistics.

[18] Arab Union of Electricity, Statistical Bulletin, 2013. [Online]. Available: https://auptde.org/en/open-data? tid $=$ All\&title $=$ \&page $=1$.

[19] Ministry of Planning \& International Cooperation. Economic Studies and for Casting Sector, 2016. [Online]. Available: https://www.devex.com/organizations/ministry-of-planning-and-international-cooperation-yemen130452.

[20] M. Kumar and D. Singh, "Improvement in head loss characteristics of fine particulate coal-water suspension with addition of coarser particulate," International Journal of Coal Preparation and Utilization, vol. 17, pp. 151-155, 2019.

[21] A. Adesanya and C. Schelly, "The profitability of onshore wind and solar PV power projects in China-A comparative study," Energy Policy, vol. 132, pp. 196-207, 2019.

[22] S. Alayan, "Design of a PV-diesel hybrid system with unreliable grid connection in Lebanon," M.S. thesis. European Solar Engineering School, 2016.

[23] Ennexos, Sunny Design Web-SMA, 2020. [Online]. Available: https://www.sunnydesignweb.com/sdweb/\#/.

[24] A. Mosheer and C. Gan, "Optimal solar cable selection for photovoltaic systems," International Journal of Renewable Energy Resources, vol. 5, pp. 28-37, 2015.

[25] S. Sumathi, L. Kumar and P. Surekha, Solar PV and Wind Energy Conversion Systems. Switzerland: Springer International Publishing, 2015. [Online]. Available at: https://www.springer.com/gp/book/9783319149400.

[26] A. Jakhrani, A. Othman, A. Rigi, S. Samo and S. Kamboh, "Estimation of carbon footprints from diesel generator emissions," in Int. Conf. in Green and Ubiquitous Technology, Bandung, Indonesia, pp. 78-81, 2012.

[27] J. Isidore, M. Radanielina and H. Tiana, "PV-hybrid off-grid and mini-grid systems for rural electrification in subSaharan Africa," Smart Grid and Renewable Energy, vol. 9, no. 10, pp. 171-185, 2018.

[28] P. Oviroh and T. Jen, "The energy cost analysis of hybrid systems and diesel generators in powering selected base transceiver station locations in Nigeria," MDPI Energies, vol. 11, pp. 687, 2018.

[29] IEA, Energy prices. Paris, 2020. [Online]. Available: https://www.iea.org/reports/energy-prices-2020. 